\title{
The Speech Act of Sermon in Javanese Language at Javanese Christian Church Kismorejo Jaten Karanganyar
}

\author{
Suwanto \\ \{yswan2001@yahoo.com\} \\ Regional Literature Study Program, of Culture Faculty, Sebelas Maret University of \\ Surakarta
}

\begin{abstract}
This research is entitled: The Speech Act of Sermon in Javanese Language at Javanese Christian Church Kismorejo Jaten Karanganyar included into descriptive qualitative research. It means this research described the language phenomenon, especially related to the speech act of the sermon in Javanese language at Javanese Christian Church Kismorejo as what it is. In accordance with its name namely GKJ most of it uses Javanese language in the sermon. The sermon at GKJ mostly uses Javanese language, until it is an interesting thing to be revealed from the side of speech act (henceforth abbreviated TT). The general purpose of this research is to document TT type in the sermon using Javanese language as the heritage from the previous generation to the recent generation (the young generation) who is almost not capable of understanding it even not knowing what it means. The particular target of this research is (1) to identify TT types in Javanese language sermon, and (2) to explain the TT meaning in Javanese language sermon. This research used descriptive qualitative method with pragmatics analysis model to identify and explain the type and meaning of the speech act in Javanese language sermon, until the sermon delivered in Javanese will be received well and correctly. Data and source of data in this research were in the form of oral data (sermon language). Data collection was conducted by using listening technique and note taking technique. Data analysis was conducted by using understanding model, contextual model, and equivalent model. The results of this research conclude that (1) TT type in Javanese Sermon at GKJ Kismorejo can be differentiated into locution TT, illocution TT, and perlocution TT; (2) the TT meaning in Javanese sermon at GKJ Kismorejo is the intention to state, order, invite, and teach.
\end{abstract}

Keywords: speech act, sermon, javanese, Javanese Christian Church

\section{Introduction}

Everyone speaks with the aims to express feeling, thought, and ideas. Utterance can be expressed orally or written. Oral language expression can be used in various needs such as dialogues, speech, and sermon. Sermon in general is done at worship places such as mosque, church, and temple [1], [2]. The sermon in those places is delivered in various languages such as Javanese, Indonesian language, and English language. The sermon by using Javanese language nowadays is still mostly found in the mosque and church included the sermon at Javanese Christian Church (henceforth; GKJ) Kismorejo Jaten Karanganyar. 
GKJ Kismorejo Jaten Karanganyar in its service to the congregation and the community still uses Javanese language. This truly attracts the attention and need to be considered and studied further concerning the usage of its language (in this case the sermon), especially related to its speech act. Thereby, Javanese sermon at GKJ Kismorejo as linguistics communication facility has speech acts. This linguistics communication is in line with the opinion by Searle (1969) saying that there is speech act in all linguistics communication.

The communication is not just a form of symbol or sentence, but more précised if called as the product or the result of the symbol or sentences in the form of speech acts (the performance of speech acts). More obviously that speech act is the product or result of certain sentence in certain condition and is the smallest unit of linguistics communication which can be in the form of statement, question, instruction, or others [3]. Speech act is an individual' psychological symptom and its sustainability is determined by the speaker's language skill in facing certain situation [4].

For example, the sermon on March 15, 2020:

Sumangga kita wiwiti sarana migatosaken sawetawis cathetan ingkang prelu [...]

'Let's start by considering some important notes $[\ldots]$ '

Based on the utterance above, it shows that the speech act used by the speaker/preacher to invite other people to do something. The type of this speech act states the speaker's (preacher's) willingness to congregations (interlocutors), namely instruction or invitation which is included into illocution speech act.

Kridalaksana defines that speech act is (1) the language act enabled by and created suitable with the grammar of language components usage; (b) the action of producing language sound regularly resulting meaningful utterance; (c) all linguistics components and non-linguistics ones covering certain complete language action concerning the participants, the form of delivering the mandate, topic, and the mandate topic; (d) the sentence pronouncement to state certain meaning from the speaker to be known by the interlocutors/listeners, mandate delivery, topic, and that mandate context, (e) the sentence pronouncement to state certain meaning from the speaker to be known by the listener. Thereby, the understanding about speech act is highly clear, until from the definition above, it can be concluded that speech act is all language and nonlanguage components covering complete language action [5]. Speech act theory according to Austin (1962) pragmatically consists of three action types embodied by the speaker, namely locutionary act, illocutionary act, and perlocutionary act [6].

\section{Research Methods}

This research was conducted by employing research method and method with the stages such as: (1) determining the research location, (2) data provision stage, (3) data analysis stage, and (4) analysis result presentation stage [7].

\section{Research Location}

The activity of this research took place at Service Area of GKJ Kismorejo Jaten Karanganyar because this area in in GKJ Kismorejo service covering three areas such as: 1) Kismorejo area located at Kismorejo hamlet, Jaten Village, Jaten Sub District, Karanganyar Regency, 2) Papahan area located at Jetak Hamlet, Papahan Village, Tasikmadu Sub District, Karanganyar 
Regency, and 3)Tasikmadu area located at Suruh Hamlet, Suruh Village, Tasikmadu Sub District, Karanganyar Regency. These three service areas during sermon Sunday worship sermon service still use Javanese language as the instruction language.

\section{Method and Technique of Data Provision}

Data provision of this research used listening method. Listening method is the method of data collection by listening to the language usage [8]. Its implementation is followed by the usage of taking note technique. The recording of relevant language data was conducted through certain transcription according to its importance [9], [10]. The first step in listening method was by using taking note technique, the researcher conducted the listening carefully and precisely towards the main data source to obtain the expected data in accordance with the research purpose.

The second step was taking note of the data obtained from the source determined in the form of data card. The next step was classifying and analyzing the language suitable with the problem until it can answer the research purpose namely to find out TT type and the meaning of each TT in Javanese sermon at GKJ Kismorejo Jaten Karanganyar [11], [12].

\section{Data Analysis Method}

This data analysis method concerns the analysis of determining the type and meaning of TT in Javanese sermon at GKJ Kismorejo Jaten Karanganyar.

a. Determining TT type in Javanese sermon

TT type determination in Javanese sermon is by using descriptive method. The basic technique is sorting technique namely all TT types in Javanese sermon obtained from the listening is sorted, and the next technique is taking note technique.

b. Determining the meaning of each TT type in Javanese sermon

The determination of each TT type was by using pragmatics analysis. The basic technique was sorting techniques namely by sorting the meaning based on the context (the hings existed out of context). To find out the meaning of each TT type in Javanese sermon was by using speech act theory by Austin (1962), Parker (1986), and Wijana (1996) [13], [14]. The next technique was taking note technique.

\section{The Method of Analysis Result Presentation}

The analysis result in the form of terms can be presented through two ways such as (1) formulation with usual words, and (2) formulation by using the signs or symbols. The first one is frequently called as informal and the second one is called as the formal method. The usage of words or symbols are the technique of presenting the analysis result [15], [16].

\section{Results and Discussion}

Based on data analysis conducted towards Javanese sermon at GKJ Kismorejo, the speech acts usage were found in two types, namely:

Speech act based on speech power, covering: locution speech act, illocution, and perlocution.

The following is the example of sermon speech act usage at GKJ Kismorejo:

a. Locution 
Context: at GKJ Kismorejo Kismorejo Area Jaten Karanganyar, Sunday sermon, April 26, 2020, Easter Week III.

Waosan Injil dinten menika nyariosaken lelampahan ingkang saged dados tuladha kangge kita sedaya bab ngadhepi prekawis ingkang wigati lan pitakenan awrat.

'The bible reading today leads us to a consideration when we face a fundamental question and difficult question.'

The speech "Waosan Injil dinten menika nyariosaken lelampahan ingkang saged dados tuladha kangge kita sedaya bab ngadhepi prekawis ingkang wigati lan pitakenan awrat" is delivered by the speaker (preacher) to the inter locutors (congregation) with the intention to inform them that the bible reading today tells about the journey which can become the example for all of us in facing a fundamental question and difficult question [17]. The speech above is the locution speech because the speaker only informs the fact without having any meaning or intention.

b. Illocution

Context: at GKJ Kismorejo Papahan Area Tasikmadu Karanganyar, Sunday sermon, May 3rd, 2020 Eastern Week IV.

Sumangga tansah emut bilih raos sumanak lan nyedulur punika ugi saged dipun-agem dening Gusti, malah saged dados srana tiyang pinangih Gusti.

'Let's always remember that friendly attitude and brotherhood can also be used by God, even it can become the facility to know/meet God.'

The speech "Sumangga tansah emut bilih raos sumanak lan nyedulur punika ugi saged dipun-agem dening Gusti, malah saged dados srana tiyang pinanggih Gusti" is delivered by the interlocutor (the preacher) to the interlocutor (congregation) with the intention to invite the interlocutor (congregation) to always behave friendly and brotherhood to other people because it is considered could be used and become the facility for other people to know/meet God.

c. Perlocution

Kontext: at GKJ Kismorejo Tasikmadu Area, Karanganyar, Sunday sermon, May 10, 2020.

Kita kedah ngajeni saha tepa slira dhateng tiyang sanes. Ananging ing bab iman kapitadosan, kita boten kepareng uwal saking bab ingkang utami lan paling wigati, inggih punika tetep pitados lan ngibadah dhumateng Gusti Yesus Kristus Sang Juru Wilujeng.

'We must respect and be self aware or respect other people. However, in the case of belief or faith, we cannot be apart from the main thing and the most important thing namely keep believing and worship God Jesus Christ The Savior.'

The speech "Kita kedah ngajeni saha tepa slira dhateng tiyang sanes. Ananging ing bab iman kapitadosan, kita boten kepareng uwal saking bab ingkang utami lan paling wigati, inggih punika tetep pitados lan ngibadah dhumateng Gusti Yesus Kristus Sang Juru Wilujeng" is delivered by the preacher to congregation with the meaning of requiring them to respect other people and forbid them to not separate from the main thing and the most important thing namely keep believing and worshipping God Jesus Christ The Savior. 
The Meaning of Javanese TT the sermon at GKJ Kismorejo Jaten Karanganyar.

a. The intent to state

Context: at GKJ Kismorejo Kismorejo Area Jaten Karanganyar, the sermon on Sunday, July 5, 2020.

Gesangipun tiyang Kristen ing jagad menika boten nate uwal saking sawernining masalah.

'The Christian's life in this world is not apart from all problems'

The speech "Gesangipun tiyang Kristen ing jagad menika boten nate uwal saking sawernining masalah is delivered by the preacher to congregation containing the intention to state that Christian's life in this world is never apart from all problems.

b. The intent to order

Context: at GKJ Kismorejo Tasikmadu Area Karanganyar, the sermon on Sunday, August 9, 2020.

Minangka tiyang pitados ingkang sampun nampeni katresnan ingkang milujengaken, kita kedah tansah sinau. Sinau madosi karsa saha rancanganipun Gusti adhedhasar Kitab Suci.

'As a believer (believing in God) who has received saving love, we must always learn. Learning to find the willingness and plan of God based on The Bible'

The speech Minangka tiyang pitados ingkang sampun nampeni katresnan ingkang milujengaken, kita kedah tansah sinau. Sinau madosi karsa saha rancanganipun Gusti adhedhasar Kitab Suci is delivered by the preacher to congregation containing the intention to order them as believers (believing in God) who has recieved saving love, then we (the congregation) must always learn. Learning to find the willingness and plan of God based on the Bible. The lingual sind stating instructing intention here is the word kedah 'must'.

c. The Intent to Invite

Context: at GKJ Kismorejo Kismorejo Area Jaten Karanganyar, the sermon on Sunday, August 9, 2020

Sumangga kita minangka pasamuwanipun Gusti kanthi estu nyamektakaken dhiri kangge nambut rawuhipun Gusti malih.

'As God's congregation, let's truly provide ourselves to welcome God's presence again (the second presence)."

The speech "Sumangga kita minangka pasamuwanipun Gusti kanthi estu nyamektakaken dhiri kangge nambut rawuhipun Gusti malih" is conveyed by the preacher to congregations containing the intention to invite, with lingual sign sumangga 'let's', and that invitation is so that the God's congregation truly provides themselves to welcome God's 'resence again (the second presence).

d. The Intent to Teach

Context: at GKJ Kismorejo Papahan Area Tasikmadu Karanganyar, teh sermon on Sunday, August 30, 2020.

Wonten piwucal saking Injil Mateus 16: 25, 26 inggih punika bentenipun nyawa kaliyan kadonyan utawi bandha. Manawi nyawa menika boten saged dipun-gantos kaliyan bandha, dene kadonyan utawi bandha nggadhahi sifat sawetawis, saged dipunudi lan dipuntumbas. 
'There is lesson in Bible Matius 16: 25, 26 is the difference between life and the world or treasure. If life cannot be exchanged with treasure, while the world or treasure has temporary trait, and can be found and bought.'

The speech "Wonten piwucal saking Injil Mateus 16: 25, 26 inggih punika bentenipun nyawa kaliyan kadonyan utawi bandha. Manawi nyawa menika boten saged dipungantos kaliyan bandha, dene kadonyan utawi bandha nggadhahi sifat sawetawis, saged dipunudi lan dipuntumbas" is delivered by the preacher to congregation containing the intent to teach, with lingual sign in the word piwucal 'teaching' and this teaching is the difference between life and the world or treasure. If life cannot be exchanged with treasure, while the world or treasure has temporary trait, could be searched and bought.

\section{Conclusion}

Based on data analysis above, then it can be concluded as follows:

a. TT (Speech Act) type in Javanese sermon at GKJ Kismorejo can be differed to be locution speech act, illocution speech act, and perlocution speech act.

b. TT (Speech Act) meaning in Javanese sermon at GKJ Kismorejo is meant to state, order, invite, and teach.

\section{References}

[1] Yohanes Suwanto, Dyah Padmaningsih, dan Endang Tri Winarni. (2017). "Tindak Tutur dalam Serat Pikukuh (Kajian Pragmatik)". (Laporan Penelitian Fundamental). Surakarta: Fakultas Ilmu Budaya Universitas Sebelas Maret.

[2] Yohanes Suwanto, Dyah Padmaningsih, dan Endang Tri Winarni. (2018). "Hak dan Kewajiban Raja dan Rakyat dalam Serat Pikukuh (Kajian Pragmatik)". (Laporan Penelitian Mandiri Aktif). Surakarta: Fakultas Ilmu Budaya Universitas Sebelas Maret.

[3] Abdul Chaer. 2003. Linguistik Umum. Jakarta: Rineka Cipta.

[4] Spradley, James P. 1997. Metode Etnografi. Yogyakarta: Tiara Wacana.

[5] Harimurti Kridalaksana. 1984. Kamus Linguistik. Jakarta: PT Gramedia.

[6] Lyons, John. 1977. Semantics II. Cambridge: Cambridge University Press.

[7] Sudaryanto (ed.). 1991. Tata Bahasa Baku Bahasa Jawa. Yogyakarta: Duta Wacana University Press.

[8] Sudaryanto. 1993. Metode dan Aneka Teknik Analisis Bahasa: Pengantar Penelitian Wahana Kebudayaan secara Linguistis. Yogyakarta: Duta Wacana University Press.

[9] D. Edi Subroto. 1992. Pengantar Metode Penelitian Linguistik Struktural. Surakarta: Sebelas Maret University Press.

[10] Edi Subroto dan Soewito. 1992. Pengantar Metode Penelitian Linguistik Struktural. Surakarta: Sebelas Maret University Press.

[11] Sutopo, HB. 1996. Metode Penelitian Kualitatif. Surakarta: UNS Press.

[12] Sutopo, HB. 1988, Metode Penelitian Kualitatif, Surakarta: Universitas Sebelas Maret Press

[13] Shri Ahimsa Putra, H. (tanpa tahun). "Bahan Kuliah Epistimologi Anthropologi". Yogyakarta: Program Pasca Sarjana UGM.

[14] Shri Ahimsa Putra, H. 1997. "Etnolinguistik: Beberapa Bentuk Kajian". Makalah. Yogyakarta: Balai Penelitian Bahasa, 26-27 Maret 1997.

[15] Rais, Wakit A., 2017. Kearifan Lokal dalam Bahasa dan Budaya Jawa: Studi Kasus Masyarakat Nelayan di Pesisir Selatan Kebumen Jawa Tengah (Kajian Etnolinguistik). Surakarta: UNS Press.

[16] Dove, Michael R. 1981. "Pengumpulan dan Penyusunan Data dalam Penelitian Antropologi". dalam Majalah Ilmu-ilmu Sastra Indonesia. Jakarta: Fakultas Sastra Universitas Indonesia. 
[17] Anton M. Moeliono (Penyunting Penyelia). 1990. Kamus Besar Bahasa Indonesia. Jakarta: Departemen Pendidikan dan Kebudayaan dan Balai Pustaka. 